\title{
The influence of solar power and solar flux on the efficiency of polycrystalline photovoltaics installed close to a river
}

\author{
Armstrong O. Njok ${ }^{1}$, Ferdinand A. Kamgba ${ }^{2}$, Manoj K. Panjwani ${ }^{3}$, Fareed H. Mangi ${ }^{4}$ \\ ${ }^{1,2}$ Department of Physics, Faculty of Sciences, Cross River University of Technology (CRUTECH), Nigeria \\ ${ }^{3,4}$ Department of Energy Systems Engineering, Sukkur IBA University, Pakistan \\ ${ }^{3}$ Renewable Energy School, North China Electric Power University, China
}

\begin{tabular}{l} 
Article Info \\
\hline Article history: \\
Received Jul 15, 2019 \\
Revised Sep 16, 2019 \\
Accepted Sep 30, 2019 \\
\hline
\end{tabular}

\section{Keywords:}

Efficiency

Photvoltaic

Solar flux

Solar power

\begin{abstract}
There is an increasing focus on utilizing the renewable energy resources, especially solar energy as the fossils are expected to deplete in near future. Solar Photovoltaics have remained of particular interest because of their relative lower overall efficiencies. Most researchers are trying to enhance the overall performance of Solar Photovoltaic and trying to study factor that may possible lead to an increase in the overall performance of a Solar Photovoltaic Panels. A thorough investigation was carried out to study the influence of solar power and solar flux on the performance parameters of Photovoltaic (Polycrystalline). The data used in the research was obtained by in-situ measurement approach using an SM206 precision digital solar power meter, a digital solar flux meter, and an M890C+ digital Multimeter. The result obtained shows an interesting correlation for current, efficiency and solar power as well as for solar flux which indicates that high solar power and solar flux positively enhances the performance of the photovoltaic. The results also reveal that once the solar power or solar flux reaching the photovoltaic exceeds $200 \mathrm{~W} / \mathrm{m} 2$ or $20 \mathrm{Klux}$, the voltage from the photovoltaic approaches maximum and remains fairly stable irrespective of the amount of solar power or solar flux reaching the photovoltaic. The data collected for three months, July, August and September shows prediction efficiency of $87 \%, 63 \%$ and $71 \%$ at 11:30am, 12:30 pm and 10:30 am respectively.
\end{abstract}

Copyright $\left({ }_{0} 2020\right.$ Institute of Advanced Engineering and Science. All rights reserved.

\section{Corresponding Author:}

Armstrong O. Njok,

Department of Physics, Faculty of Sciences,

Cross River University of Technology (CRUTECH), Nigeria.

Email: Njokarmstrong@ crutech.edu.ng

\section{INTRODUCTION}

The sun which is an average star has been burning for more than 4-billion years and will continue to burn at least that long into the future before erupting into a giant red star, engulfing the earth in the process. The sun is responsible for nearly all of the energy available on earth, and while producing these energies releases $95 \%$ of its output energy as light, some of which cannot be seen by the human eye [1].

Even though the sun ranks as a run-of-the-mill star, it releases a huge quantity of energy in terms of human capacity or need. Power output per second is $3.86 \times 10^{20}$ megawatts (MW) [1], several billion times the electric capacity of Nigeria utilities. This energy fills the solar system, bathing the earth's atmosphere with a near constant supply of 1.37 kilowatts per square meter $\left(\mathrm{kW} / \mathrm{m}^{2}\right)$.

Approximately $99 \%$ of solar or short wave radiation at the earth's surface is contained in the region from 0.3 to $3.0 \mu \mathrm{m}$ while most of terrestrial or long wave radiation is contained in the region of 3.5 to $50 \mu \mathrm{m}$. Outside the earth's atmosphere, solar radiation has an intensity of approximately $1370 \mathrm{watts} / \mathrm{metre}^{2}$. This is the value at mean earth-sun distance at the top of the atmosphere and is referred to as solar constant. On the 
surface of the earth on a clear day, at noon, the direct beam radiation will be approximately $1000 \mathrm{watts} / \mathrm{metre}^{2}$ for many locations, at sea level [2]. The availability of energy is affected by location (including latitude, and elevation), season, and time of the day. All of which can be readily determined. However the biggest factors affecting the availability of energy are cloud and other meteorological conditions which may vary with location and time.

Solar energy impinging upon a transmitted medium or target is partly reflected and absorbed; the remainder is transmitted. The relative values are dependent upon the optical properties of the transparent object and the solar spectrum [3]. Solar radiation is partially depleted and attenuated as it traverses the atmospheric layers, preventing a substantial portion of it from reaching the earth's surface. This phenomenon is due to absorption, scattering and reflection in the upper atmosphere (stratosphere), with its thin layer of ozone and the lower atmosphere (troposphere) within which cloud formations occur and weather conditions manifest themselves.

Solar radiation and solar flux are evidently a determining factor when it comes to studying the natural potential of solar energy as a source of renewable energy. They are described by the visible and near infrared radiation emitted from the sun. The different spectrums are described by their wavelength that range within the broad range of 0.20 to $4.0 \mu$ (microns). Photovoltaic electricity is produced directly from sunlight by converting the energy in sunlight into free charged particles within certain kinds of materials through a process known as the photovoltaic effect. The photovoltaic (PV) effect is the basis of the conversion of light to electricity in photovoltaic, or solar cells. Thus it is important to notice that the performance of the photovoltaic panel in real time outdoor condition is different than conventional laboratory conditions [4] Nigeria stands at the threshold of rapid depletion of conventional energy resources [5], as such; renewable energy source (such as solar) should be identified as an attractive area for research and should receive substantial attention for investment purposes. In many rural locations of Nigeria, solar energy could provide a unique and cost effective way of supplying both metropolitan and rural areas with energy. Economic and agricultural activities take place in these areas with little or no access to energy and clean water supply.Chegaar et al. [6] studied the effect of illumination intensity on solar cells parameters using the one diode model. The study results indicated that the short circuit current, the photocurrent, the ideality factor and the maximum power increases linearly with increasing irradiance intensity at room temperature in the considered irradiance intensity range $\left(160-1000 \mathrm{~W} / \mathrm{m}^{2}\right)$. El-Shaer et al. [7] investigated the effect of light intensity and temperature on crystalline silicon solar modules parameters using xenon lamp (150W) as a solar simulator. The results of their investigation from the two crystalline modules reveal that light intensity has a dominant effect on current parameters. Short circuit current and maximum current increases linearly with increasing light intensity. The investigation further reveal that maximum power density output increased by $80 \%$ with increasing light intensity from 0.2 Sun to 1.0 Sun. Tobnaghi \& Naderi [8] researched on the effect of solar radiation and temperature on solar cells performance. Their research shows that short circuit current is directly proportional to the light intensity, while open circuit voltage changes logarithmically with light intensity. Omubo-pepple et al. [9] carried out a research on the effect of temperature, solar flux and relative humidity on the efficient conversion of solar energy to electricity using a B-K Precision module 615 digital light instrument and PV modules in Port Harcourt. Their research shows that there is a direct proportionality between current, solar flux and efficiency. Ettah et al. [10] studied the relationship between solar radiation and the efficiency of solar panels in Port Harcourt, Nigeria. From their study it was observed that a positive linear relationship exist between solar flux and current as well as efficiency. Omubo-pepple et al. [11] carried out a study on the influence of meteorological parameters on the efficiency of photovoltaic module in cities in the Niger Delta of Nigeria. Their study reveals that metrological parameters such as relative humidity, solar flux and temperature have significant effects on the efficiency of solar panels. Hamrouni et al. [12] studied how solar radiation and ambient temperature affects the performances of a PV pumping system while employing the Simulink tool. Their simulated results show that large solar radiation increases both the global efficiency and the pump flow. Touati et al. [13] researched on the effects of environmental and climatic conditions on PV efficiency in Qatar employing monocrystalline and amorphous PV technologies. From their result it was obvious that for both technologies the power obtained increases linearly with the amount of radiation received. Rani et al. [14] worked on the effect of temperature and irradiance on solar module performance. Their result shows that with increasing solar irradiance reaching the panel, the power output of the cell increases. Syafiqah et al. [15] reported that the increase in the operating temperature directly leads to the reduction of output power from Photovoltaic Panels. Leow et al. [16] investigated the performance difference in the PV panel subjected to difference in the wind velocity. The results encouraged exposure of the photovoltaic panels to operate in the open atmosphere with considerable wind velocity for achieving better output power. Khanna et al. [17] studied the effect of climate on electrical performance of finned phase change material integrated solar photovoltaic and discovered that under clear sky, finned phase change material is more beneficial. More heat is produced and thus requires external cooling due to large incidence 
of solar flux. Schubert \& Spinner [18] researched on solar simulator spectrum and measurement uncertainties and found that a solar simulator made of 19 led lights can be compared to an industry standard filtered xenon solar simulator. Berthod et al [19] studied the variability of temperature coefficients of mc-Si solar cells with irradiance and established that the variation of temperature coefficients of a solar cell is a function of irradiance. Miloudi et al [20] worked on solar tracking with photovoltaic panel and found that a follow up is required of photovoltaic system of the sun trajectory if the power output is to be optimized. Bhattacharya et al [21] found that the correlation between wind speed and efficiency is not very good as compared to the correlation between ambient temperature and efficiency after investigating the effects of ambient temperature and wind speed on the performance of monocrystalline solar photovoltaic module in Tripura, India. Siddiqui \& Bajpai [22] reports that the performance of PV modules varies with location and environmental conditions surrounding it, after investigating the deviation in the performance of solar module under climatic parameter as ambient temperature and wind velocity in composite climate. Ettah et al [23] investigated the effects of solar panel temperature on the power output efficiency in Calabar, Nigeria and came to a conclusion that high solar panel temperatures may have serious adverse effects on the efficiency of solar panels. Jiang et al [24] carried out experimental investigation of the impact of airborne dust deposition on the performance of solar photovoltaic (PV) modules and revealed that under the same dust concentration, a faster degradation process is enhanced when polycrystalline PV modules are packaged with epoxy than with glass surface. The novelty and the aim of this research lies with the thorough investigation on the influence of solar power and solar flux on the performance and efficiency of Photovoltaics installed for residential households use in atmosphere close to river which is not yet investigated especially in the Nigeria's prospects.

\section{MATERIALS AND METHOD}

\subsection{Materials}

A 130 watt polycrystalline solar panel with dimension of $1480 * 670 * 35 \mathrm{~mm}$ and capacities of 7.18A and $18.10 \mathrm{~V}$ at maximum current and voltage respectively. Charge controller was utilized to assure smooth charging of the lead acid battery with specification of $(12 \mathrm{~V}-75 \mathrm{AH})$. A digital multimeter (M890C+) was utilized to monitor voltage and current values, accompanied by a $\mathrm{K}$ type thermocouple for measuring temperature in Celsius. A digital solar power meter (SM206) was also used which is capable of measuring solar power in Watt per square metre $\left(\mathrm{W} / \mathrm{m}^{2}\right)$ and also in British thermal unit (Btu). A mastech digital solar flux meter (MS6616) was utilized to carefully monitor the solar flux.

\subsection{Methods}

The solar panel was placed horizontally flat facing the sun on a platform one metre high above the ground as can be referred from Figure 1(a). Connecting cables were connected to the output terminals of the solar panel. From the output terminals of the solar panel the cables were connected to the charge controller. The output of the charge controller was then connected to the battery for charging the battery which powered the load through an inverter followed by Grid connection as can be seen from Figure1(b). Measurements were taken at an interval of 30 minutes from $6.00 \mathrm{am}$ to $6.00 \mathrm{pm}$ for a period of 90 days (30 days each in the month of July, August and September). During measurements, the voltage and current from the panel were measured using the digital multimeter. The time of day was recorded and the amount of solar flux and solar power reaching the PV panel were also measured using a digital lux (light) meter and a digital solar power meter respectively.From the readings obtained, the power from the solar panel was determined using (1), the maximum power that the solar panel can give out can be calculated using (2), while the normalized power output efficiency was calculated using (3) as shown by [25]. It has been shown by [10] that the efficiency of a photovoltaic module can be determined using (4). [25] Also show that the short circuit current and the open circuit voltage are been influenced by parameters like solar power and temperature as indicated in (5) and (6).

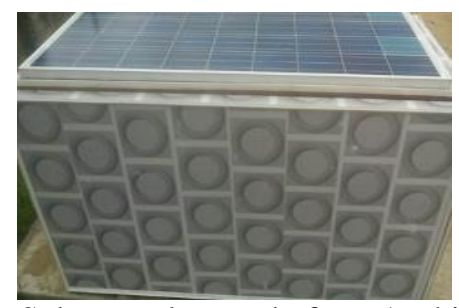

a). Solar panel on a platform $1 \mathrm{~m}$ high

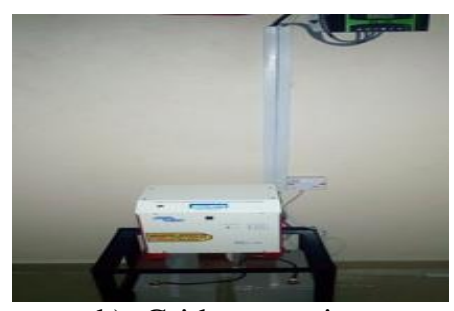

b). Grid connection

Figure 1. The experimental layout 


\subsection{Equations}

Measured Power:

$$
\text { Pmea }=\text { Vmea } \mathrm{x} \text { Imea }
$$

Maximum power:

$$
P \max =V \max x \operatorname{Imax}
$$

Normalized power output efficiency:

$$
\eta_{\mathrm{p}}=\frac{P_{\text {mea }}}{P_{\max }} \times 100
$$

Module efficiency:

$\eta_{\text {mod }}=\frac{\text { Power of solar panel } \times 100 \%}{\text { Area of solar panel } \times 1000 \mathrm{~W} / \mathrm{m}^{2}}$

Short circuit current:

$$
I s c=\mathrm{bH}
$$

Open circuit voltage:

$$
\mathrm{V}_{\mathrm{oc}}=\frac{K T}{Q} \ln \frac{I s c}{I o}
$$

Where $P_{\text {mea }}, V_{\text {mea }}$ and $I_{\text {mea }}$ are the measured power, voltage and current respectively. $P_{\max }, V_{\max }$ and $I_{\max }$ are the maximum power, voltage and current respectively that the module can give out. $\mathrm{Q}$ is the electronic charge, $I_{0}$ is the saturation current, $T$ is the absolute temperature of the photovoltaic module, $b$ is a constant depending on the properties of the semiconductor junction, $\mathrm{K}$ is the Boltzmann constant and $\mathrm{H}$ is the incident solar power (light intensity) on the photovoltaic module.

\subsection{Study Area}

Calabar, the capital of Cross River State is located in the southern part of Nigeria, located on Latitude 40 57'06' ' $\mathrm{N}$ and longitude $8^{0} 19^{\prime} 19^{\prime}$ ' $\mathrm{E}$ at an elevation of $32 \mathrm{~m}$ above sea level experiences the tropical monsoon with a lengthy wet season spanning ten months and a short dry season covering the remaining two months. The harmattan, which significantly influences weather in West Africa is noticeably less pronounced in the city. Temperatures are relatively constant throughout the year, with average high temperatures usually ranging from 25 to 28 degrees Celsius. There is also little variance between daytime and nighttime temperature, as temperatures at night are typically only a few degrees lower than the daytime high temperature. Calabar averages just less than 3,000 millimeters (120 in) of precipitation annually. But the location selected for this study is on Latitude $4{ }^{0} 57^{\prime} 38.6161$ " $\mathrm{N}$ and Longitude $8^{0} 18^{\prime} 58.482$ " E, it is about 400metre away from the Calabar River as shown in Figure 2.

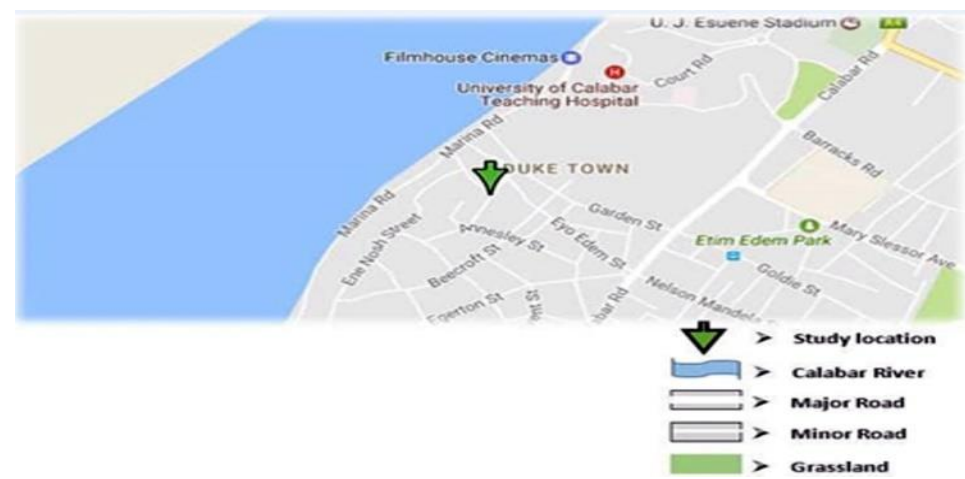

Figure 2. Map showing study location 


\section{RESULTS AND DISCUSSION}

Figure 3 shows how the photovoltaic module responds in terms of voltage production to an increasing amount of solar power received from the sun. It reveals that above a solar power of $200 \mathrm{~W} / \mathrm{m}^{2}$ the voltage output remains fairly constant irrespective of the amount of solar power received. This shows that maximum voltage can be expected from photovoltaic modules as early as 9am.

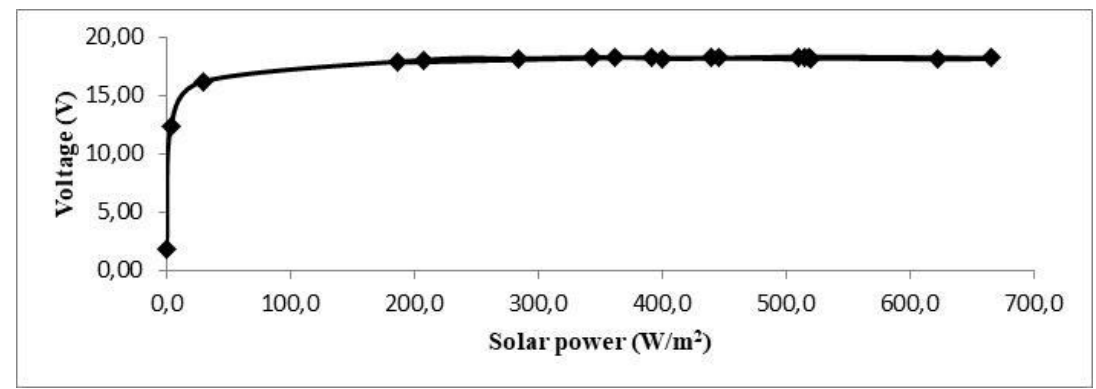

Figure 3. Voltage (V) against solar power $\left(\mathrm{W} / \mathrm{m}^{2}\right)$

Figure 4 reveals the effects of solar power on the current of the photovoltaic module. It clearly shows a very high positive correlation between current and solar power. This very high positive correlation tell us that increasing solar power favors an increase in current; this conforms to our statistical correlation, showing that linear relationship exist between solar power and current. Which is in agreement with studies by Ettah et al. [10].

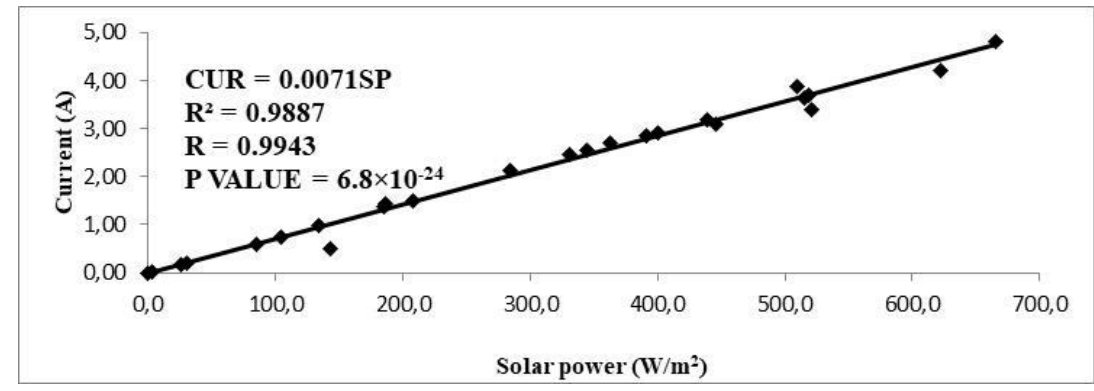

Figure 4. Current (A) against solar power $\left(\mathrm{W} / \mathrm{m}^{2}\right)$

Figure 5 also clearly shows a very high positive correlation between the efficiency of the module and solar power. This very high positive correlation reveals that the efficiency of the photovoltaic module is enhanced as the amount of solar power reaching it increases, which is also in agreement with studies by Ettah et al. [10].

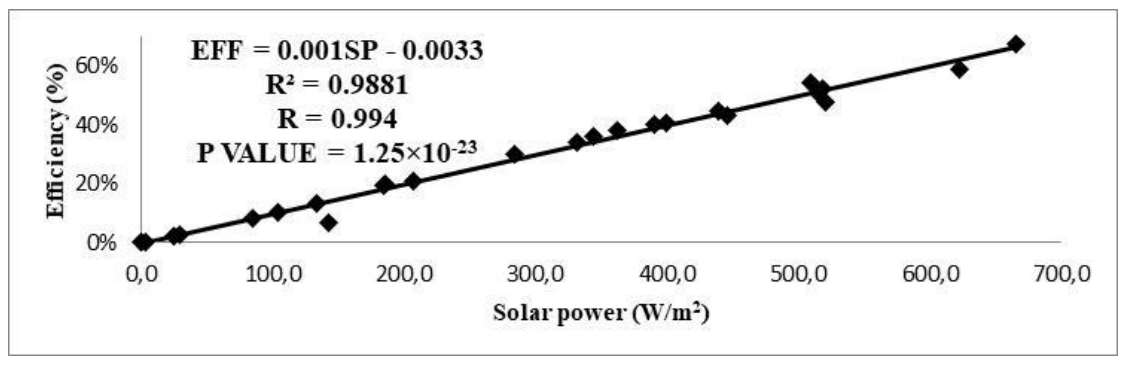

Figure 5. Efficiency $(\%)$ against solar power $\left(\mathrm{W} / \mathrm{m}^{2}\right)$ 
Figure 6 shows how the photovoltaic module responds to increasing amount of solar flux in terms of voltage production. It reveals that above a solar flux of 20klux the voltage output remains fairly constant irrespective of the amount of solar flux reaching the panel. This further reveals that the photovoltaic module is expected to produce its maximum voltage once the brightness of the sun reaches or exceed $20 \mathrm{Klux}$.

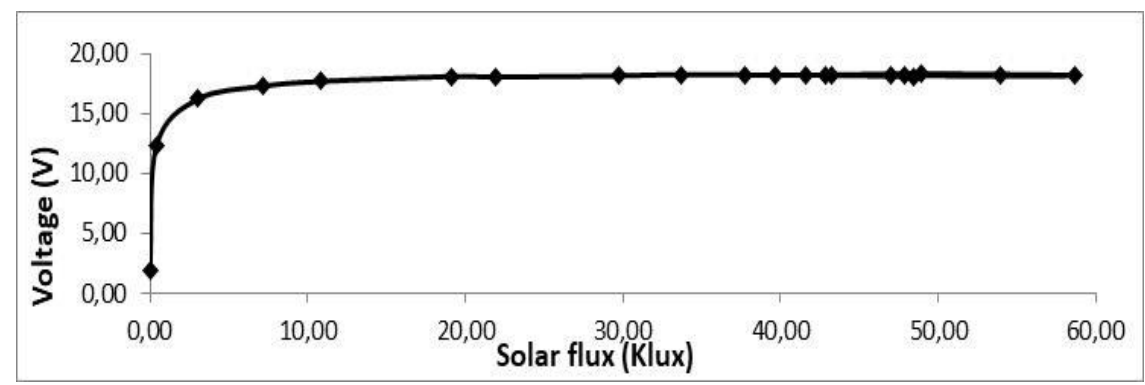

Figure 6. Voltage (V) against solar flux (Klux)

Figure 7 and Figure 8 show the effect of solar flux on the current and efficiency of the photovoltaic module respectively. These figures clearly show very high positive correlations which indicate that increase in solar flux enables an increase in current and efficiency. This conforms to our statistical correlations showing that linear relationships exist between solar flux and current and also solar flux and efficiency. Both figures are in agreement with studies by Omubo-pepple et al. [9].

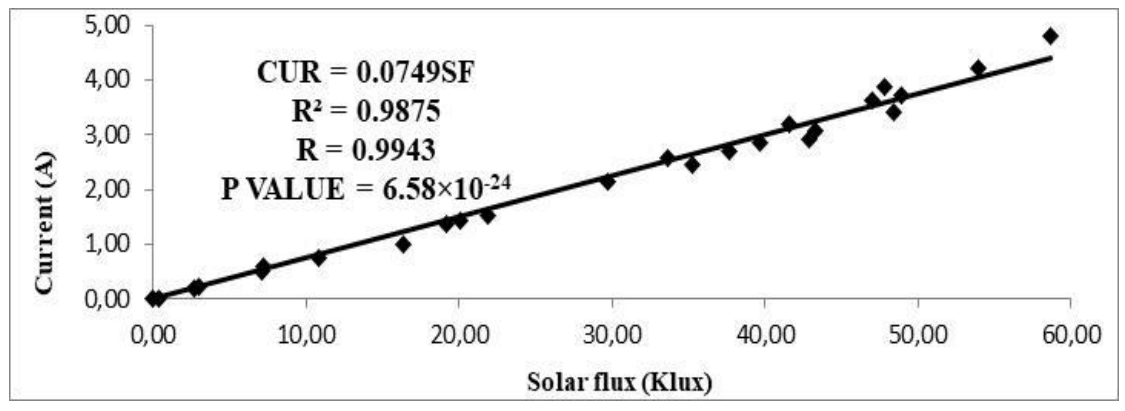

Figure 7. Current (A) against solar flux (Klux)

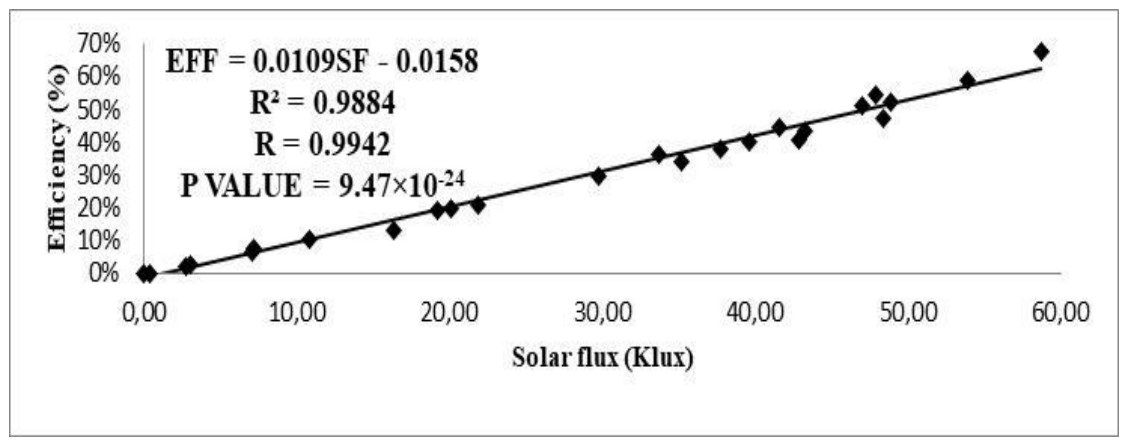

Figure 8. Efficiency (\%) against solar flux (Klux)

Figure 9 depicts the way that a photovoltaic module responds in terms of voltage and current production with increasing efficiency. It reveals that from $0 \%$ to $20 \%$ efficiency, an increase in voltage is observed, from $20 \%$ and above, the voltage remains fairly stable, while current continues to increase linearly as efficiency from the photovoltaic module increases. 


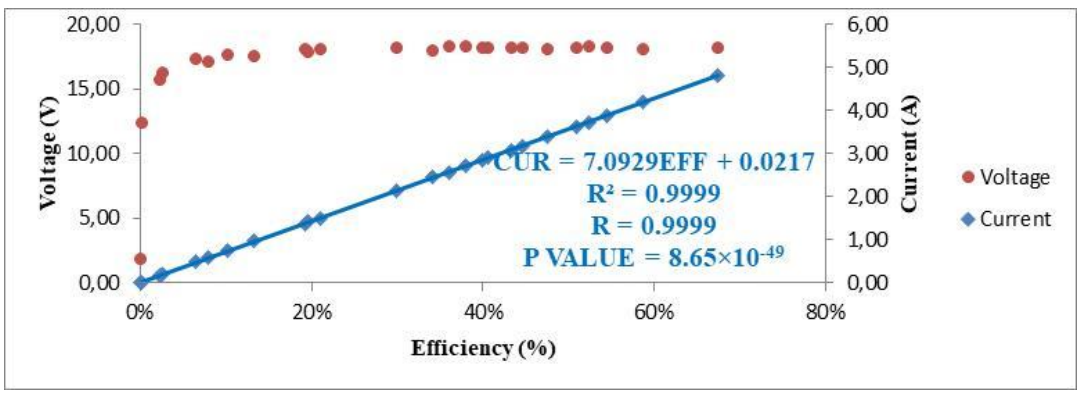

Figure 9. Voltage (V) and current (A) against efficiency (\%)

Figure 10 shows the efficiency of the photovoltaic module for the three months in which data was recorded. It shows that in the month of July, a peak efficiency of 87\% at 11:30am should be expected from the photovoltaic module. In the month of August, the highest efficiency to be expected from the photovoltaic module is $63 \%$ at $12: 30 \mathrm{pm}$. While in the month of September, double peaks in efficiency at 10:30am $(71 \%)$ and 2:00pm (70\%) should be expected.

Figure 11 shows the average efficiency of the photovoltaic module before noon, after noon and for full daytime, for the months of July, August and September. It shows that the photovoltaic module was more efficient before noon in the month of September and less efficient in August, with the efficiency of July lying in between. This was because the average solar power received by the photovoltaic module before noon in the month of September was higher, followed by July and the less in August as shown in Figure 12. The photovoltaic module was least efficient after noon in the month of September, while reaching the same efficiency in the months of July and August. This was due to the fact that the average solar power received by the photovoltaic module after noon in the month of September was the lowest, while July and August almost had the same level of solar power as shown in Figure 12. For the average efficiency produced by the photovoltaic module during the day, the photovoltaic module was more efficient $(33 \%)$ in the month of September due to the high average solar power received.

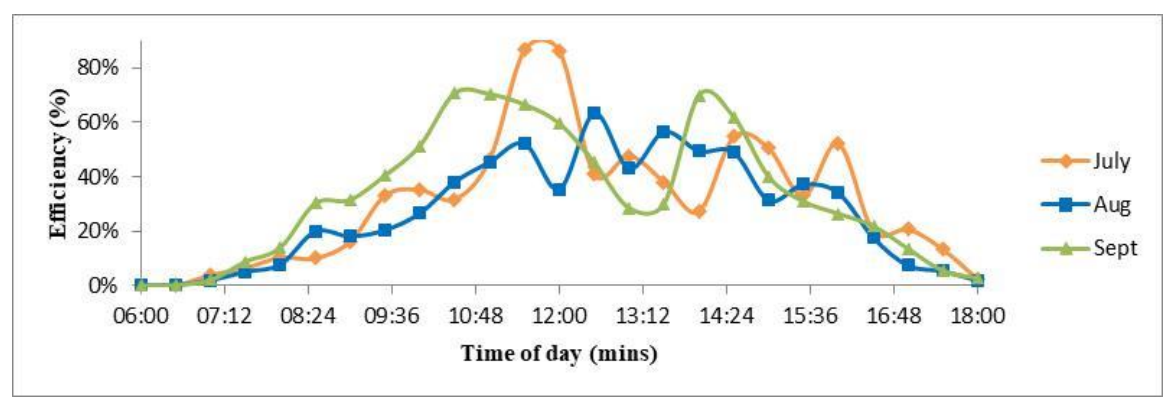

Figure 10 Efficiency (\%) against time of day (mins) for the month of July, August and September

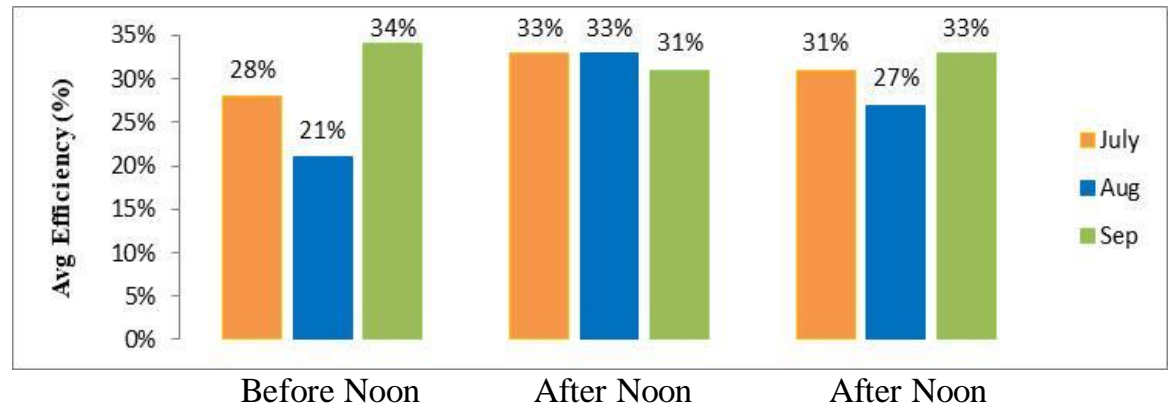

Figure 11. Average efficiency produced by the module before noon, after noon and during the day for the month of July, August and September 


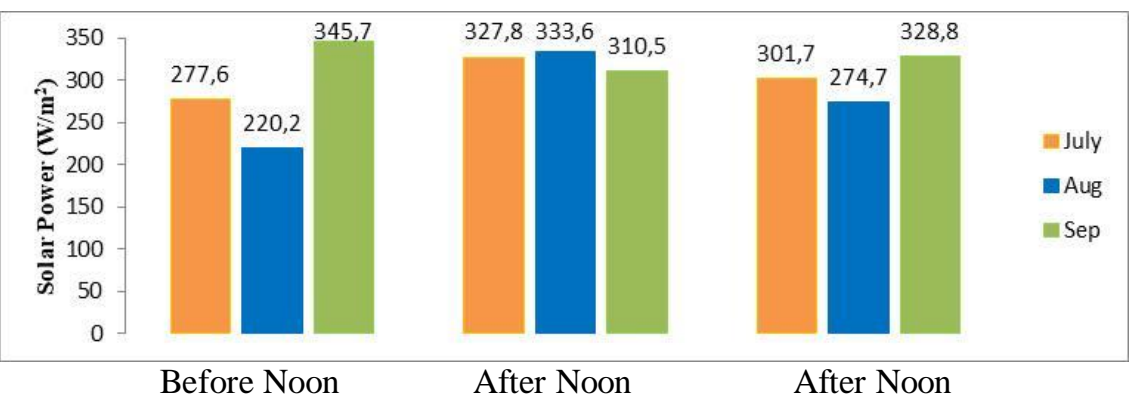

Figure 12. Average solar power across the module before noon, after noon and during the day for the month of July, August and September

\section{CONCLUSION}

Our results shows that the output voltage from the photovoltaic approaches maximum and remains fairly stable once the solar power or solar flux reaching the photovoltaic exceeds $200 \mathrm{~W} / \mathrm{m}^{2}$ or $20 \mathrm{Klux}$ respectively. The result also shows a very high positive correlation for current, efficiency and solar power as well as for solar flux which indicates that high solar power and solar flux positively enhance the performance of the photovoltaic. Current produced increases linearly with efficiency but the voltage remains fairly stable above $20 \%$ efficiency. For the months in which data was acquired, the photovoltaic module was more efficient in the month of July followed by September and less efficient in the month of August. The application of photovoltaic technology in the conversion of solar energy to electricity within the location under study in the months of July, August and September can be said to be favorable.

\section{CHALLENGES AND RECOMMENDATIONS}

It is recommended that this same research be carried out on monocrystalline and thin film solar photovoltaics installed for street lighting and household use close to the river for the location under study.

\section{COMPETING INTERESTS}

Authors have declared that no competing interests exist.

\section{REFERENCES}

[1] Baghzouz, Y. "Photovoltaic Devices III". Retrieved March 6, 2017, from http://www.egr.unlv.edu/ eebag/Photovoltaic\%20Devices\%20III.pdf.

[2] Rackat, A. (2005). The relative flux density of photosynthetically active radiation. New York, Academic press, 355.

[3] Dietz, A. G. (2002). Diathermanous Materials and properties of surface, in zaren: Introduction to the utilization of solar energy. New York, McGraw Hill, 359.

[4] Sabri, Y. H., Hasan, W. Z. W., Shafie, S., Radzi, M. A. M., Sabry, A. H. (2018). Daily Harvested Energy of Cadmium Telluride Thin Film Photovoltaic. Indonesian Journal of Electrical Engineering and Computer Science, 11(1), 18-26.

[5] Kamgba, F. A., Edet, C. O. \& Njok, A. O. (2017). Effects of some meteorological parameters on wind energy potential in Calabar, Nigeria. Asian journal of physical and chemical sciences, 4(1), 1-7.

[6] Chegaar, M., Hamzaoui, A., Namoda, A., Petit, P., Aillerie, M., \& Herguth, A. (2013). Effect of illumination intensity on solar cells parameters. Energy Procedia, 36(2013), 722-729.

[7] El-Shaer, A., Tadros, M. T. \& Khalifa, M. A. (2014). Effect of light intensity and temperature on crystalline silicon solar modules parameters. International Journal of Emerging Technology and Advanced Engineering, 4(8), 311318.

[8] Tobnaghi, D. M. \& Naderi, D. (2015). The effect of solar radiation and temperature on solar cells performance. Extensive journal of applied sciences, 3(2), 39-43.

[9] Omubo-Pepple, V. B., Isreal-cookey, C. \& Alaminokuma, G. I. (2009). Effects of Temperature, Solar Flux and Relative Humidity on the Efficient Conversion of Solar Energy to Electricity. European Journal of Scientific Research, 35(2), 173-180.

[10] Ettah, E. B., Obiefuna, J. N. \& Njar, G. N. (2011). The relationship between solar radiation and the efficiency of solar panels in Port Harcourt, Nigeria. $\quad$ International Journal of Applied Science and Technology, 1(4), 124126. 
[11] Omubo-Pepple, V. B., Tamunobereton-ari, I. \& Briggs-Kamara, M. A. (2013). Influence of meteorological parameters on the efficiency of photovoltaic module in cities in the Niger Delta of Nigeria. Journal of Asian scientific research, 3(1), 107-113.

[12] Hamrouni, N., Jraidi, M. \& Cherif, A. (2008). Solar radiation and ambient temperature effects on the performances of a PV pumping system. Revue des Energies Renouvelables, 11(1), 95-106.

[13] Touati, F., Massoud, A., Hamad, A. \& Saeed, S. A. (2013). Effects of environmental and climatic conditions on PV efficiency in Qatar. Renewable Energy and Power Quality Journal, X(11), ISSN 2172-038.

[14] Rani, S. P., Giridhar, S. M. \& Prasad, S. R. (2018). Effect of temperature and irradiance on solar module performance. IOSR Journal of Electrical and Electronics Engineering, 13(2), 36-40.

[15] Syafiqah, Z., Irwan, Y. M., Amin, N. A. M., Irwanto, M., Leow, W. Z., \& Amelia, A. R. (2017). Thermal and Electrical Study for PV Panel with Cooling System. Indonesian Journal of Electrical Engineering and Computer Science, 7(2), 492-499.

[16] Leow, W. Z., Irwan, Y. M., Asri, M., Irwanto, M., Amelia, A. R., Syafiqah, Z. \& Safwati, I. (2016). Investigation of solar panel performance based on different wind velocity using ANSYS. Indonesian Journal of Electrical Engineering and Computer Science, 1(3), 456-463.

[17] Khanna, S., Reddy, K. S. \& Mallick, T. K. (2018). Effect of climate on electrical performance of finned phase change material integrated solar photovoltaic. Solar Energy, 174, 593-605.

[18] Schubert, S. \& Spinner, D. (2016). Solar Simulator Spectrum and Measurement Uncertainties. Energy Procedia, 92, 205-210.

[19] Berthod, C., Strandberg, R., Yordanov, G. H., Beyer, H. G. \& Odden, J. O. (2016). On the variability of the temperature coefficients of mc-Si solar cells with irradiance. Energy Procedia, 92, 2-9.

[20] Miloudi, L., Acheli, D. \& Chaib, A. (2013). Solar Tracking with Photovoltaic Panel. Energy Procedia, 42, 103-112.

[21] Bhattacharya, T., Chakraborty, A. K. \& Pal, K. (2014). Effects of Ambient Temperature and Wind Speed on Performance of Monocrystalline Solar Photovoltaic Module in Tripura, India. Journal of Solar Energy, Vol 2014, Article ID 8170778, 5 pages.

[22] Siddiqui, R. \& Bajpai, U. (2012). Deviation in the performance of Solar Module under climatic parameter as Ambient Temperature and Wind Velocity in Composite Climate. International Journal of Renewable Energy Research, 2(3), 486-490.

[23] Ettah, E. B., Eno, E. E. \& Udoimuk, A. B. (2009). The Effects of Solar Panel Temperature on the Power Output Efficiency in Calabar, Nigeria. Journal of Radiography \& Radiation Sciences, 23, 1-7.

[24] Jiang, H., Lu, L. \& Sun, K. (2011). Experimental investigation of the impact of airborne dust deposition on the performance of solar photovoltaic (PV) modules. Atmospheric Environment, 45(25), 4299-4304.

[25] Njok, A. O. \& Ogbulezie, J. C. (2018). The effects of relative humidity and temperature on polycrystalline solar panels installed closed to a river. Physical Science International journal, 20(4), 1-11. 